\author{
EVALUATION OF THE \\ ANTIOXIDANT ACTIVITY OF THE \\ AQUEOUS AND METHANOLIC \\ EXTRACTS OF SEEDS OF PERSEA \\ AMERICANA MILL, VARIETY HASS, \\ FROM THE STATE ARAGUA IN \\ VENEZUELA

\section{EVALUACIÓN DE LA ACTIVIDAD ANTIOXIDANTE DE LOS EXTRACTOS ACUOSO Y METANÓLICO DE SEMILLAS DE PERSEA AMERICANA MILL, VARIEDAD HASS, PROVENIENTES DEL ESTADO ARAGUA EN VENEZUELA}

Received 07142020

Accepted 08132020

Published 08302020

Vol. 37, No.3, pp. 142-147, Jul./Ago.2020 Revista Boliviana de Química

37(3), 142-147, Jul./Aug. 2020 Bolivian Journal of Chemistry

DOI : $10.34098 / 2078-3949.37 .3 .2$

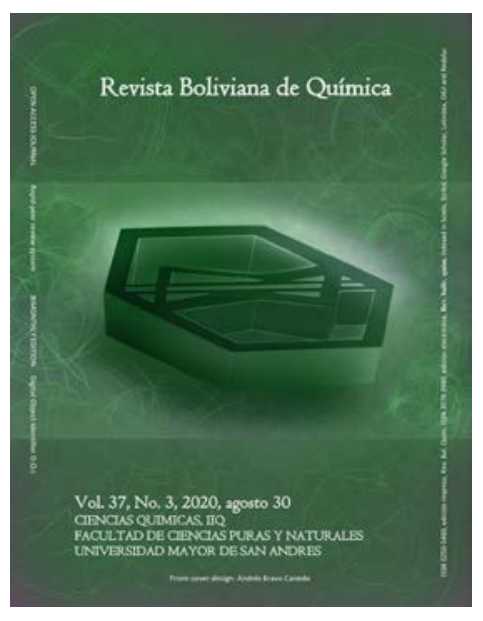

Short report

Peer-reviewed

Franklin Pacheco-Coello*, Desirée Seijas-Perdomo

School of Health Sciences, Department of Basic Sciences, Laboratory of Chemistry and Instrumental Analysis, Laboratory of Heavy Metals and Organic Solvents, Agro-Industrial Biotechnology Section of the "Dr. Francisco J. Triana Alonso" Biomedical Research Institute (BIOMED-UC) University of Carabobo, Postal Code 2103, phone +2446004000 , Ruiz Pineda Street, La Morita II, Santa Rita Sector, Aragua State, Venezuela

Keywords: Avocado, Antioxidant, Total phenols, FRAP, DPPH, ABTS.

Palabras clave: Palta, Antioxidante, Fenoles totales, FRAP, DPPH, ABTS.

\title{
ABSTRACT
}

The high content of bioactive compounds in Persea americana seed has generated great interest worldwide due to its various potentialities, in which its antioxidant capacity stands out. The objective of the study was to evaluate the antioxidant activity of the aqueous and methanolic extracts of Persea americana Mill seeds, variety Hass, sold in supermarkets in the city of Maracay, Venezuela. The total phenol content of the extract was determined through the Folin-Ciocalteau method to then evaluate the antioxidant activity by three chemical methods (DPPH, FRAP and ABTS). A higher concentration of total phenolic compounds was obtained in the methanolic extract, with a statistical difference with respect to the aqueous extract. The antioxidant activity was higher in the methanolic extract in the three methods used $(\mathrm{p}<0.05)$. These results show the high antioxidant power of the avocado seed, considered as a waste product, which allows proposing strategies that allow its use for medicinal purposes.

*Corresponding author: pachecofranklin74@gmail.com

\section{RESUMEN}

Downloadable from: Revista Boliviana 
El alto contenido de compuestos bioactivos en la semilla de Persea americana, ha originado un gran interés a nivel mundial por sus diversas potencialidades, en la que destaca su capacidad antioxidante. El estudio tuvo como objetivo evaluar la actividad antioxidante de los extractos acuoso y metanólico de semillas de Persea americana Mill, variedad Hass, comercializadas en supermercados de la ciudad de Maracay, Venezuela. Se determinó el contenido de fenoles totales del extracto a través del método Folin-Ciocalteau para luego evaluar la actividad antioxidante por tres métodos químicos (DPPH, FRAP y ABTS). Se obtuvo una mayor concentración de compuestos fenólicos totales en el extracto metanólico, con diferencia estadística respecto al extracto acuoso. La actividad antioxidante fue superior en el extracto metanólico en los tres métodos empleados $(\mathrm{p}<0.05)$. Estos resultados muestran el alto poder antioxidante de la semilla de aguacate, considerada como producto de desecho, lo que permite proponer estrategias que permitan su uso con fines medicinales.

\section{INTRODUCCIÓN}

Avocado is an evergreen tree belonging to the order Ranales, family Lauraceae and genus Persea, native to Central America and Mexico that can now be found in most tropical and subtropical regions of the world, such as in Colombia, Perú and Venezuela [1,2]. Among the species is the Persea americana classified by Miller, which developed several subspecies due to its geographical isolation, which originated different botanical types [3,4]. Avocado consumption has increased because it is increasingly valued by consumers, not only for its unique taste and texture but also for its health benefits [5,6].

The separation, isolation and characterization of phenolic compounds in foods, specifically in avocado waste, not only increases the possibility of increasing the number of phytochemicals that can improve the quality of life of people, but also the alternative of using waste by-products (epicarp and seed) at industrial level and thus achieve a comprehensive use of this fruit [7]. Seeds have been found to possess insecticidal, fungicidal and antimicrobial activities with a high content of phenolic compounds, which play an important role in potential health effects [8]. Therefore, the purpose of the present study was to evaluate the antioxidant capacity of the aqueous and methanolic extracts of avocado seed (Persea americana Mill, variety Hass) by three chemical methods.

\section{EXPERIMENTAL}

\section{Origin of plant material (PM)}

The seeds were obtained from avocados sold in a super market in the city of Maracay, Aragua state, Venezuela.

\section{Sample preparation for extraction}

To obtain the alcoholic extract, $10 \mathrm{~g}$ of plant material were weighed and previously crushed, placing them in a $400 \mathrm{~mL}$ beaker with $300 \mathrm{~mL}$ of $70 \% \mathrm{v} / \mathrm{v}$ methanol/water. It was macerated and left to rest for $24 \mathrm{~h}$, and then it was subjected to microwave radiation for $15 \mathrm{~s}$ with a power of $125 \mathrm{MHz}$. The extracts were filtered, using Whatman filter paper number 4 . The extract was left to macerate for $24 \mathrm{~h}$, filtering with Whatman filter paper number 4[9].

\section{Determination of total phenolics}

For the determination of total phenolics, $50 \mu \mathrm{L}$ of the alcoholic extract were mixed with $250 \mu \mathrm{L}$ of the Folin-Ciocalteu $1 \mathrm{~N}$ reagent (Analytical grade, Merck). It was left to stand for 8 minutes and then $750 \mu \mathrm{L}$ of $20 \% \mathrm{Na}_{2} \mathrm{CO}_{3}$ and $950 \mu \mathrm{L}$ of distilled water were added. Was incubated for $30 \mathrm{~min}$ at room temperature and the absorbance was read on a Genesis 20 UV/VIS spectrophotometer (Thermo Scientific, Waltham, Massachusetts, USA). A calibration curve for Gallic Acid (Sigma-Aldrich, Germany) was prepared with concentrations of 50, 100, 200, 300, 400, 500 and 1000 ppm. The results were expressed in mg of Gallic Acid Equivalents (GAE) / g of PM [10].

\section{Ferric-Reducing Antioxidant Power (FRAP) Assay}


Franklin Pacheco-Coello et Desirée Seijas-Perdomo RBQ Vol. 37, No.3, pp. 142-147, 2020

The FRAP test was used to determine the reducing capacity of infusions [11]: $100 \mu \mathrm{L}$ of infusion were mixed with 3 $\mathrm{mL}$ of FRAP reagent consisting of a mixture of $300 \mathrm{mM}$ sodium acetate and acetic acid buffer, $10 \mathrm{mM}$ TPTZ solution (2,4,6-tri(2-pyridyl)-s-triazine), and $20 \mathrm{mM} \mathrm{FeCl}_{3}$ solution, in a volume ratio of 10:1:1.

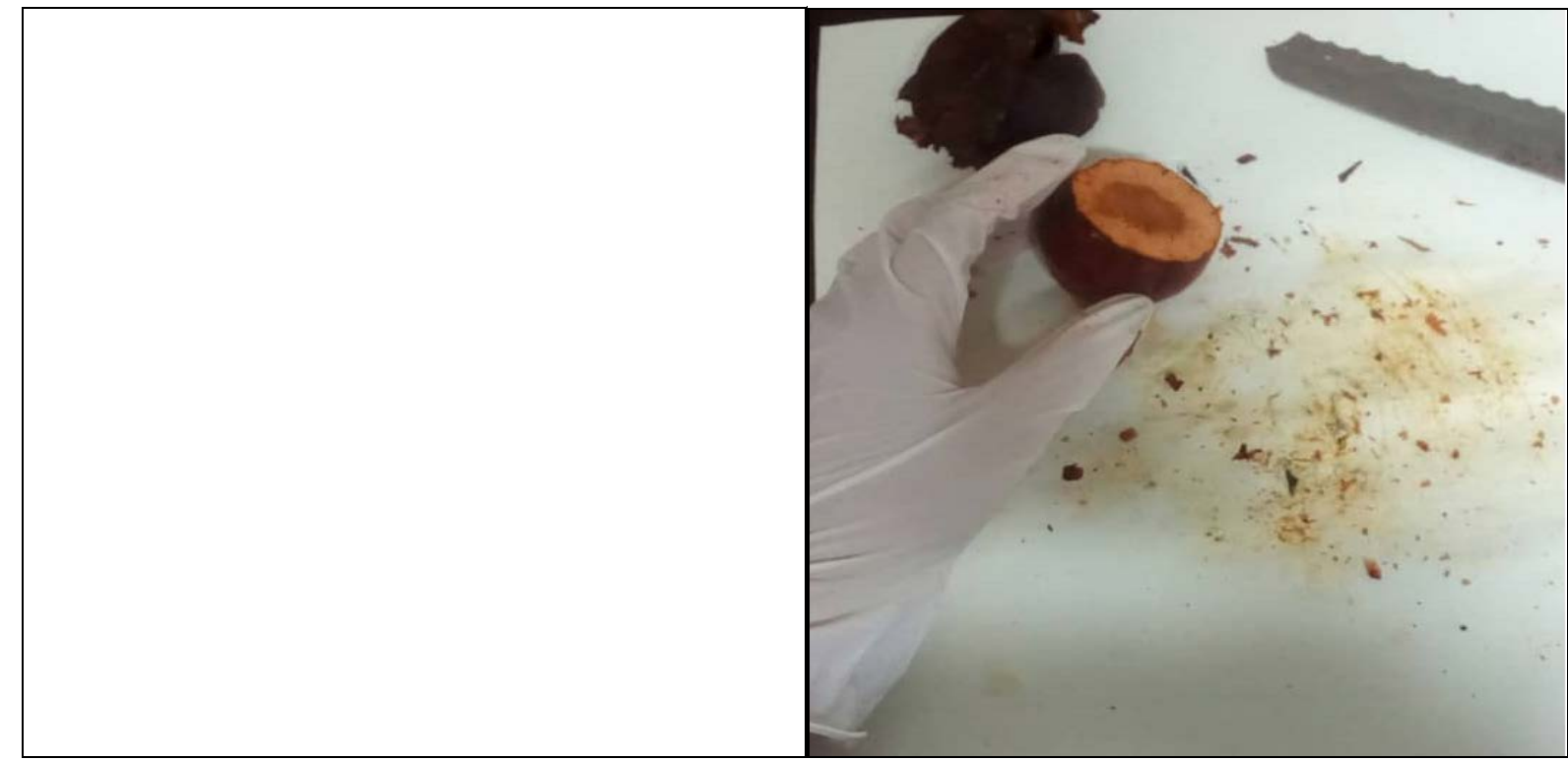

Figure 1. Avocado seeds

The reaction was carried out at room temperature for $4 \mathrm{~min}$, and absorbance was recorded at $593 \mathrm{~nm}$ using a Genesis 20 UV/VIS spectrophotometer (Thermo Scientific, Waltham, Massachusetts, USA). $\mathrm{FeSO}_{4}$ was used as standard, and the results were expressed as $\mu \mathrm{mol} \mathrm{Fe}^{2+} / \mathrm{g} \mathrm{PM}$.

\section{Free radical 2,2-diphenyl-1-picrylhydrazyl (DPPH) Assay}

$100 \mu \mathrm{L}$ of sample and $2.9 \mathrm{~mL}$ DPPH (100 mM solution of DPPH in $80 \%$ methanol) (Sigma Aldrich) were placed together in a quartz cell. Absorbance (Genesis 20 UV/VIS spectrophotometer) was monitored every 5 min for 30 min at a wavelength of $515 \mathrm{~nm}$. The reference absorbance $\left(\mathrm{A}_{0}\right)$ was obtained by substituting the sample volume for $80 \%$ methanol. The percentage of DPPH reduction was obtained with the equation DPPH $(\%)=\left(A_{0}-A_{n}\right) 100 / A_{0}$, where $A_{0}$ and $A_{n}$ were the reference and sample absorbance, respectively [12]. The data were used to determine the IC $_{50}$ parameter, which represents the concentration $\left(\mu \mathrm{g} \cdot \mathrm{mL}^{-1}\right)$ of phenolic compounds required to reduce the DPPH free radicals by $50 \%$ [5].

\section{2,2'-Azino-bis (3-ethylbenzothiazoline-6-sulfonic acid Assay (ABTS)}

This test is based on the ability of antioxidants to sequester the cation radical ABTS ${ }^{\bullet+}\left(7 \mathrm{mM}\right.$ with $\mathrm{K}_{2} \mathrm{~S}_{2} \mathrm{O}_{8}$ at 2.45 $\mathrm{mM}$ )[13]. The reaction mixture was kept in the dark at room temperature for $14 \mathrm{~h}$. After time, the ABTS ${ }^{\bullet+}$ solution was diluted with ethanol to obtain an absorbance of $0.70 \pm 0.02$ at $734 \mathrm{~nm}$, using a Genesis 20 UV/VIS spectrophotometer (Thermo Scientific, Waltham, Massachusetts, USA). Subsequently, $250 \mu \mathrm{L}$ of ABTS+ solution diluted with methanol was added to $10 \mu \mathrm{L}$ of sample. Radical reduction was monitored for $5 \mathrm{~min}$ at $734 \mathrm{~nm}$, using ascorbic acid (Vitamin C) as standard. The results were expressed in $\mathrm{mg} / \mathrm{mL}^{-1}$.

\section{Statistical analysis}

All determinations were made fivefold and the values were expressed as the means \pm the standard deviation. Statistical differences were determined by analysis of variance (ANOVA) by using the Statistic 9.0 program for Windows.

\footnotetext{
Downloadable from: Revista Boliviana 144 de Química. Volumen 37 №3. Año 2020
} 


\section{RESULTS AND DISCUSSION}

\section{Total Phenolics of the extracts}

Prior to the evaluation of the antioxidant activity of the extracts, the concentration of total Phenolics was determined in triplicate, obtaining a concentration of $26.32 \pm 2.45 \mathrm{mg} \mathrm{GAE} / \mathrm{g} \mathrm{PM}$ in the aqueous extract and 57, $32 \pm 2.45 \mathrm{mg}$ GAE/g PM for the methanolic extract, observing a statistical difference $(\mathrm{p}=0.035)$. The difference observed is similar to that reported in several studies carried out with Persea americana Mill, which indicate that the extraction of phenolic compounds is influenced by the type of solvent used [14,15]

\section{Antioxidant activity}

The antioxidant capacity was determinate as recommended by several studies, which indicate that at least two methods should be used to evaluate the antioxidant activity of an extract [16-18]. The antioxidant effect by the DPPH and FRAP method is shown in Table 1. The antioxidant capacity observed by the DPPH and FRAP methods shows that the extracts possess an important source of antioxidant compounds, a conclusion specially valid when compared to other studies worldwide, which indicate that avocado seeds can be used as a functional food ingredient or as an antioxidant additive $[19,20]$.

Table 1. Antioxidant activity of extracts.

\begin{tabular}{llcc}
\hline \multicolumn{1}{c}{ Extracts } & Methanolic & Aqueous & $p$ \\
\hline FRAP $(\mathrm{Fe}+2 / \mathrm{g}$ MP $)$ & $118.2 \pm 1.13$ & $95.11 \pm 0.24$ & 0.041 \\
DPPH $\left(\mu \mathrm{g} \cdot \mathrm{mL}^{-1}\right)$ & $46.2 \pm 0.17$ & $64.80 \pm 0.13$ & 0.039 \\
\hline \multicolumn{2}{c}{ For each method, means + SD. Significantly different $(p<0.05)$. }
\end{tabular}

For each method, means \pm SD. Significantly different $(p<0.05)$.

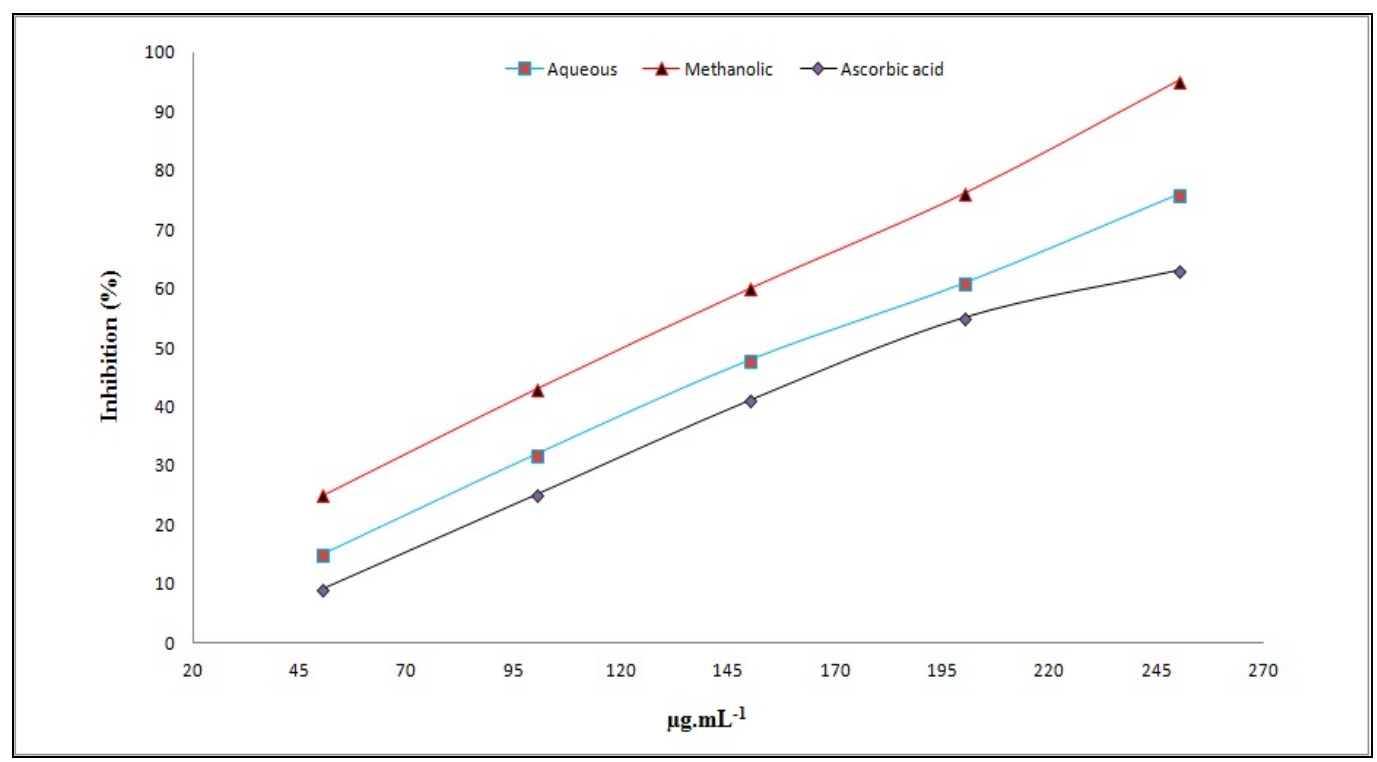

Fig 2. Evaluation of antioxidant activity by ABTS method

Among the methods used to determine the capacity of an antioxidant to capture free radicals, the ABTS radical is one of the most applied, as it is considered highly sensitive, practical, fast and very stable [21]. The ABTS assay showed

\footnotetext{
Downloadable from: Revista Boliviana 145 de Química. Volumen 37 №3. Año 2020
} 
Franklin Pacheco-Coello et Desirée Seijas-Perdomo RBQ Vol. 37, No.3, pp. 142-147, 2020

higher inhibition in the methanolic extract with statistical difference from the aqueous extract (Figure 2). These results coincide with what was reported in Bogota Colombia, whose study consisted in determining the phenolic profile of avocado byproducts, among them the seed, indicating that the extracts showed an antioxidant capacity (ABTS method) related to their content of bioactive compounds, considering these byproducts for pharmaceutical and industrial use [15].

\section{CONCLUSIONS}

We may conclude that the seed of Persea americana Mill variety Hass, constitutes an excellent source of phenolic compounds with high antioxidant power, conditioned to the way in which these are extracted from the plant material. Finally, this study supports and extends what has been found in several countries where avocado is a daily food, with high projection of exportation from South America to the Asian continent.

\section{REFERENCES}

1. Bernal, J. Manual técnico, actualización tecnológica y buenas prácticas agrícolas en el cultivo de aguacate. 2da Edición, 2014, Medellín, Colombia., 1-410.

2. Geering, A. 2018, A review of the status of Avocado sunblotch viroid in Australia, Australasian Plant Pathology, 47, 555-559. DOI: https//doi.org/10.1007/s13313-018-0592-6

3. Gómez-López, V. 2002, Fruit characterization of high oil content avocado varieties, Scientia agricola, 59, 403-406. DOI: https//doi.org/10.1590/S0103-90162002000200030

4. Shafer, A., Wolf, J., Alves, P., Bergstrom, L., Bruford, M., Brannstrom, I., Colling, G., Dalén, L., De Meester, L., Ekblom, R., Fawcett, K., Fior, S., Hajibabaei, M., Hill, J., Hoezel, A., Höglund , J., Jensen, E., Krause, J. 2015, Genomics and the challenging translation into conservation practice, Trends Ecol. Evol, 30, 78-87. DOI: https//doi.org/10.1016/j.tree.2014.11.009.

5. Giffoni, J., Salles, E., Aguiar R., Nogueira R., Costa, J. 2009, Chemical composition,toxicity and larvicidal and antifungal activities of Persea Americana (avocado) seed extracts, Revista da Sociedade Brasileira de Medicina Tropical, 42 (2), 110-113. DOI: https//doi.org/10.1590/S0037-86822009000200003

6. Haminiuk, C., Maciel, G., Plata-Oviedo, M., Peralta, R. 2012, Phenolic compounds in fruits -an overview. International Journal of Food Science and Technology, 47 (10), 1-22. DOI: https//doi.org/10.1111/j.1365-2621.2012.03067.x

7. Rodríguez-Carpena, J.G., Morcuende, D., Andrade, M.J., Kylli, P., Estévez, M. 2011, Avocado (Persea americana Mill.) phenolics in vitro antioxidant and antimicrobial activities, and inhibition of lipid and protein oxidation in porcine patties, J. Agric. Food Chem, 59, 5625-5635. DOI: https://doi.org/10.1021/jf1048832

8. Chouhan, S., Sharma, K.,Guleria, S. 2017, Antimicrobial Activity of Some Essential Oils—Present Status and Future Perspectives, Medicines, 4, 58. DOI: https//doi.org/10.3390/medicines4030058

9. Pabón, L., Venegas, J., Rendón, M., Arias, R., Hernández P. 2013, Actividad antioxidante y antibacteriana de extractos de hojas de cuatro especies agroforestales de la Orinoquía colombiana, Revista Cubana de Plantas Medicinales, 18 (1), 57-70

10. Ayala-Zavala, J.F., Silva-Espinoza, A.B., Cruz-Valenzuela, R.M., Villegas-Ochoa, M.A. 2013, Antioxidant and antifungal potential of metanol extracts of Phenillus sp, Revista Iberoaméricana de Micolología, 29 (3), 132-138.

11. Benzie, I.F.F., Strain, J.J. 1996, The ferric reducing ability of plasma (FRAP) as a measure of "Antioxidant power”: The FRAP assay, Analytical Biochemistry, 239, 70-76.

12. Soler-Rivas, C., Espín, J.C., Wichers, H.J. 2000, An easy and fast test to compare total free radical scavenger capacity of foodstuffs, Phytochemical Analysis, 11(2), 330-338.

13. Re, R., Pellegrini, N., Proteggente, A., Pannala, A., Yang, M., \& Rice - Evans, C. 1999, Antioxidant activity applying an improved ABTS radical cation decolorization assay, Free Radical Biology and Medicine, 26, 1231-1237. DOI: https://doi.org/10.1016/S0891-5849(98)00315-3.

14. Kim, D., Chun, O., Kim, Y., Moon, H., Lee, L. 2003, Quantification of polyphenolics and their antioxidant capacity in fresh plums, Journal of Agricultural and Food Chemistry, 51(22), 6509-6515. DOI: https://doi.org/10.1021/jf0343074

15. Rosero, J., Cruz, N., Osorio, C., Hurtado, N. 2019, Analysis of phenolic composition of byproducts (seeds and peels) of Avocado (Persea americana Mill.) cultivated in Colombia, Molecules, 24 (17), 23-45. DOI: https://doi.org/10.3390/molecules24173209

16. Higdon, J., Frei, B. 2003, Tea catechins and polyphenols: health effects, metabolism, and Antioxidant Functions, Critical Reviews in Food Science and Nutrition, 43(1), 89-143. DOI: https://doi/org/10.1080/10408690390826464

17. Liu, Q., Tang, G.Y., Zhao, C.N., Liu, F.A., Siu, Y.U. 2019, Antioxidant activities, phenolic profiles, and organic acid contents of fruit vinegars, Antioxidants, 8(6), 8-78. DOI: https://doi.org/10.3390/antiox8040078

18. Xu, D.P., Li, Y., Meng, X., Tang, Y.U. 2017, Natural antioxidants in foods and medicinal plants: Extraction, assessment and resources, Journal of Molecular Sciences, 18(3), 118-124. DOI: https://dx.doi.org/10.3390\%2Fijms18010096.

19. Kosińska, A., Karamać, M., Estrella, I., Hernández, T., Bartolomé, B., Dykes, G. 2012, Phenolic compound profiles and antioxidant capacity of Persea americana Mill. Peels and Seeds of Two Varieties, Journal of Agriculture Food Chemistry, 60, 4613- 4619. DOI: https://doi/org/dx.doi.org/10.1021/jf300090p|

20. Dabas, D., Shegog, R., Ziegler, G., Lambert, G. 2013, Avocado (Persea americana) seed as a source of bioactive phytochemicals, Current Pharmaceutical Design, 19, 6133-6140. DOI: https://doi.org/10.2174/1381612811319340007.

Downloadable from: Revista Boliviana 146 de Química. Volumen 37 No3. Año 2020


ISSN 2078-3949 Rev. boliv. quim. Electronic edition
Franklin Pacheco-Coello et Desirée Seijas-Perdomo RBQ Vol. 37, No.3, pp. 142-147, 2020

Published 0830 2020; DOI:10.34098/2078-3949.37.3.2

21. Arnao, M.B. 2000, Some methodological problems in the determination of antioxidant activity using chromogen radicals: a practical case, Trends Food Sci. Technol, 11, 419-421. DOI: https://doi.org/10.1016/S0924-2244(01)00027-9 